\section{TOUGH CRIME LAWS ARE FALSE PROMISES}

\section{Franklin E. Zimring*}

The narrowest version of the three-strikes-andyou're-out plan under consideration by Congress is one of the mildest forms of this approach now being discussed. This proposal only applies if defendant is convicted in federal court of a serious, violent offense after two previous convictions in a state or federal court for violent crime.

Most three-strikes proposals have added drug offenders, burglars and other criminals to the group that would be subjected to mandatory life in prison on a third conviction. The proposed three-strikes law would allow some deserving individuals to regain freedom after 25 years of time served, while other versions offer no alternative to geriatric prison populations-facilities that are soon to be overstuffed with long-retired burglars who may not pose a threat to society at an advanced age and who may need increased medical care in prison. In this season of panic-driven crime legislation, it might seem meanspirited of me to express doubts about a program that is clearly focused on violent crime.

But even a watered-down three-strikes plan is a step in the wrong direction. The federal plan that Edwin Meese presumably favors is unnecessary. It also is unprincipled, dangerous, ineffective and detracts from programs that might reduce violence. Once the current system of sentencing federal offenders is fully understood, a new three-strikes proposal has literally nothing to recommend it.

Does federal criminal law need a new provision to deal with repetitive, violent offenders? How many violent, three-time losers are processed in our federal courts? Do the seriously violent get light sentences in court or early release from federal prisons? The congressional three-strikes debates have been almost fact-free. But a survey of law and practice leads to the conclusion that the three-strikes proposal is designed to solve a problem that does not exist in federal criminal justice.

For starters, anyone who thinks the U.S. Sentencing Commission is lenient has been out of the country for a long time. The complex sentencing guidelines that have governed federal criminal justice since 1987 are a hard-liner's dream, with doses of federal prison provided for most crimes and very long terms meted out for serious crimes of violence. The chairman of

* William Simon Professor of Law and Director of the Earl Warren Legal Institute, University of California at Berkeley. Reprinted with permission from Insight Magazine, May 16, 1994, Vol. 10, Issue No. 20, p. 21, c 1994. All rights reserved. the commission sounded surprised and alarmed when responding to the tone in Congress:

"Some critical comments directed toward the criminal justice system in general-'revolving door' prisons; early release through parole; too generous 'good time' provisions; and lenient and/or unequal sentencing by individual judges-do not apply to the federal system. The Sentencing Reform Act, together with the sentencing guidelines that it mandated, has already addressed these issues. The sentencing guidelines... ensure that federal sentences are certain, firm and proportional."

And the Sentencing Commission did not stop at "certain, firm and proportional" prison terms for the general categories of offenders. At the direction of Congress, it anticipated the three-strikes approach and provided separate treatment for career criminals under the sentencing guidelines. The kidnapper, rapist or other person convicted of the top grade of violent offenses can now qualify for a career-criminal sentence carrying a 30-year minimum and a life-term maximum. Armed robbery under the career-criminal guidelines carries a sentence between 262 and 326 months.

Therefore, the current system provides sentences that can be longer than those in the Meese proposal.

Why, then, the need for a three-strikes proposal? One answer might be that the proposal is mandatory, while the federal prosecutor can exercise discretion over the current career-criminal guideline. But this distinction evaporates when the special nature of federal criminal justice is understood. Unlike county district attorneys who have primary responsibility for prosecuting crime, federal prosecutors can pick and choose their cases and decline to prosecute the others. If the local prosecutor does not take jurisdiction, the offender goes free. Nationwide, federal prosecutors turn down about three-fourths of the criminal cases offered to them.

If federal prosecutors can decline any case, a threestrikes provision is nothing more than an option. To understand this fact is to understand that the proposal being put forward in the House will provide no new tools for the war on criminal recidivists.

This raises an interesting question: How does this kind of deja-vu proposal come to occupy center stage in the federal crime bill? Congress may not have noticed the overlap between current rules and the new proposal because legislative attention has been focused on public opinion polls rather than on the statute books.

Three strikes was conceived from a sense of political rather than operational necessity in Congress and the White House. The proposal is an attempt to follow the lead of states where a three-strikes program has become a significant political force. The need in Congress is to capture the rhetorical high ground. Never mind that federal courts see less than 5 percent of violent offenders. Ignore the fact that federal sentencing already provides all that this 
FALSE PROMISES

proposal promises. These facts are not important, because the struggle in Washington is over the political custody of a slogan rather than the practical reality of sentencing.

The detached observer might ask, "So what's the harm in redundancy? After all, if the new proposals don't change much, they won't cost much either. Why not let Congress make its political statement and give thanks that it will have little practical impact?" But every proposal of this type is a time bomb, because there is no limiting principle to protect it from wild expansion. It can be stretched in an infinite number of different directions. There is no penal theory or body of empirical research to suggest that three convictions-instead of two or four-for separate offenses has any special predictive significance. There is no logical reason to limit a recidivist definition to violent offenses.

In the past, some three-time loser statutes have covered all felonies, and a ragtag collection of incompetent forgers and bungling burglars served life terms in the prisons of England and the United States. Since nobody in the current debate seems to remember this experience, we may be well on the way to watching history repeat itself. All it takes is a simple legislative amendment to add burglaries or drug offenses to the list of eligible felons. There are threetime loser and habitual-felon statutes on the books in more than 30 states, many of which provide for life imprisonment. Most of these laws include gardenvariety property felonies in their coverage. Under those circumstances, it is far from prudent to assume that Congress will confine coverage to violent offenses.

The impact of adding new categories is staggering. When residential burglary was included in the 1994 California laws, the cost of the law more than tripled and its focus went from 100 percent violent crimes to 70 percent burglaries. Adding drug crimes to the federal bill, as the Senate has started to do, would dramatically inflate the federal program because drug offenders are the majority of all defendants in federal courts.

There is a further detail to consider when thinking about three strikes. Extending the long terms violent federal offenders already serve is a lousy way to reduce the crime rate. Violent crime is a young-man's game, and the best way to use prison cells to reduce crime is to confine high-rate offenders during the years of their maximum risk. A life-term extension will only help crime prevention if 60 - and 70 -year-old bank robbers are a real problem. A quick look at our crime statistics shows that preemptive lifetime imprisonment to prevent a geriatric crime wave in 2020 is far from the fast track to public safety.

Indeed, the symbolic politics of three strikes may help to keep our streets dangerous because it is a distraction from our real problems. Congressman $X$ votes for this type of sound-bite crime control and then tells his constituents that he has addressed their concerns about violence. While Congress spends time and effort on mythical beasties like soft-hearted sentencing commissions and septuagenarian rapists, semiautomatic gunfire is heard on the streets of the District of Columbia. Politicians will happily postpone the hard choices that confront us on violence if campaigns such as three strikes offer them a risk-free alternative.

And three strikes is a baseball metaphor that might not hold in an election year. The day after he signed the broadest three-strikes law of recent times, California Gov. Pete Wilson put forward a one-strike proposal. All proposals such as the one before Congress merely open the bidding on the content of life-term laws. Smart bookies would give odds that three-strikes fever will spread in the current atmosphere to a broader assortment of crimes and criminals.

Many who support narrow versions of threestrikes legislation are holding their noses when they do so; they hope to minimize the harm of an approach they dislike to limiting the coverage of the law to a few serious offenders. The idea is to give the public the symbolic vindication of life terms at a very small actual cost. This kind of damage control is believed widely to be the motive for New York Gov. Mario Cuomo's proposal of a law that much resembles the federal proposal.

A damage-control approach to three strikes creates problems of principle and practicality. Once you have embraced mandatory minimum life terms for some offenders, an important issue of principle has been conceded to those who would wish the same fate for drug sellers or residential burglars. It is very rare in penal policy that a small quantity of bad policy achieves a social benefit.

It is rare also to find that small quantities of penal excess will satisfy an angry and fearful public when larger punishments and wider coverage are proposed. A chief occupational hazard of damage control is its ineffectuality. Offering up a little bit of three strikes is like trying to satisfy a grizzly bear by offering him half your lunch.

The frenzy over three strikes is a symptom of a larger problem: the dominance of populist politics in making criminal justice policy. Political debate about criminal justice has always been full of snake-oil remedies and false promises.

But the legal and governmental process used to be insulated from naked politics by government officials and legislators who respected expertise and factual data. The framework of government allowed judges and parole boards to operate independently of immediate political pressure.

In recent times, as crime has become a hot-button issue in federal and state government, every detail of

criminal justice policy has become a political issue,

Continued on page 77 